\section{Clinical implications}

- Historically, tuberculosis has been associated with poverty

- Notification rates for tuberculosis have increased in the United Kingdom since 1987

- This study shows that tuberculosis remains more common in underprivileged people

- An increased diagnostic awareness of tuberculosis, particularly when dealing with underprivileged patients, is required

diagnosis is necessary. Far from diminishing, tuberculosis both worldwide and in the United Kingdom is increasing. Poverty may be a factor causing this increase.

1 Black D. Inequalities in health. Report of a research working group. London: Department of Health and Social Security, 1980.

2 Whitehead M. The health divide. In: Inequalities in Health. London: Penguin, 1988:215-399.

3 Winkelstein W, Kantor S, Davies EW, Maneri CS, Mosher WE. The relationship of air pollution and economic status to total mortality and relationship of air pollution and economic status to total mortality and

selected respiratory mortality in men. Arch Environ Health 1967;14:162-71.
Holland WW, Halil T, Bennett AE, Elliott A. Factors influencing the onset of Holland WW, Halil T, Bennett AE, Elliott A. Fa
chronic respiratory disease. BMf 1969;ii:205-8.

5 Citron KM, Girling DJ. Tuberculosis. In: Weatherall DJ, Ledingham JGG, Warrell DA, eds. Oxford textbook of medicine. Oxford: Oxford University Press, 1987:5. 278-99.

6 Seaton A, Seaton D, Leitch AG, eds. Crofion and Douglas' respiratory disease. Oxford: Blackwell, 1989:375-77.
7 Office of Population Censuses and Surveys. Communicable Diseases 1987-1990. London: HMSO, 1988-1991. (Series MB2, No 14-17.)

8 Centers for Disease Control. MMWR 1990;39(10):1-2.

9 Brundney K, Dobkin J. Resurgent tuberculosis in New York City. Human immunodeficiency virus, homelessness and the decline of tuberculosi control programs. Am Rev Respir Dis 1991;144:745-9.

10 Nisar M, Narula $M$, Beeching N, Davies PDO. HIV related tuberculosis in England and Wales. Tubercle and Lung Disease 1992;73:200-2.

11 Mersey Regional Health Authority. Information unit small area database. Liverpool: Mersey Regional Health Authority, 1991.

12 Stillitoe K. Ethnic origin: the search for a question. Population Trends 1978;13: 25-30.

13 Townsend P, Phillimore P, Beattie A. Health and deprivation: inequalities and the North. London: Croon Helm, 1988.

4 Jarman B. Identification of underprivilaged areas. BMf 1983;286:1705-9.

15 Platt MJ, Ashton JR. Health and deprivation in Mersey region. Liverpool District Health Authority University of Liverpool, 1991. (Observatory Report Series No 2.)

16 Fraser WM. Duncan of Liverpool. London: Hamish Hamilton, 1947.

17 Department of Health. Public health common data set. London: Department of Health, 1990

18 Office of Population Censuses and Surveys. Census 1991, preliminary returns. London: HMSO, 1992

19 Medical Research Council Cardiothoracic Epidemiology Group. National survey of notifications of tuberculosis in England and Wales in 1988. Thorax 1992;47:770-5.

20 Davis PDO, Williams CSD, Hotchkiss J, Jones A, Syed Q. The standardised notification ratio for tuberculosis: a simple way of assessing service needs (abstract). Thorax 1992;47:875.

21 McMurray DN, Kimball MS, Tetzlaff CL, Mintzer CL. Effects of protein deprivation and BCG vaccination on alveolar mactophage function in pulmonary tuberculosis. Am Rev Respir Dis 1986;133:1081-5.

22 McMurray DN, Bartow RA. Immunosuppression and alteration of resistance to pulmonary tuberculosis in guinea pigs by protein undernutrition. $₹ \mathrm{Nutr}$ 1992;122:738-43.

23 Leitch AG. Audit of tuberculosis contact tracing procedures in South Gwent. Respic Med 1992;86:173-5.

24 Schoeman JH, Westaway MS, Neethling A. The relationship between socioeconomic factors and pulmonary tuberculosis. Int $\mathcal{f}$ Epidemiol 1991;20 435-40.

(Accepted 15 fuly 1993)
Departments of

Paediatrics, Radiology, and

Medical Audit,

Gloucestershire Royal

Hospital, Gloucester

GL1 3NN

Lyda Jadresic, senior registrar in paediatrics

Nicola Cowie, medical audit facilitator

Brian Witcombe, consultant radiologist

David Stevens, consultant

paediatrician

Public Health Laboratory, Gloucestershire Royal

Hospital

Keith Cartwright, director

Correspondence to:

Dr Jadresic.

BMf 1993;307:761-4

\title{
Investigation of urinary tract infection in childhood
}

\author{
Lyda Jadresic, Keith Cartwright, Nicola Cowie, Brian Witcombe, David Stevens
}

Abstract

Objectives-To determine the number of laboratory confirmed urinary tract infections in children and to ascertain general practitioners' practices and attitudes towards their investigation and management.

Design-Prospective one year survey of urine specimens submitted for bacteriological investigation; review of radiology department records; questionnaire survey of general practitioners.

Setting-Gloucester health district.

Subjects -57432 children aged $<15$ and 7143 children aged $<2$ registered with a general practice in Gloucester health district and their 195 general practitioners.

Results-4317 urine specimens were submitted from children aged $<15$, of which 563 from 442 children were culture positive. The rate (number/100 children/practice) of culture positive urine specimens in these children varied more than 10 -fold between general practices, and this correlated closely with the rate of referral of urine specimens for investigation. A follow up specimen to check for clearance of infection was taken in $22 \%(125 / 563)$ of infections. Of the 821 specimens submitted from children aged $<2,103$ from 89 children were positive. Of these children, 28 underwent radiological imaging. Most general practitioners would aim to obtain bacteriological confirmation of urinary tract infection on weekdays but only a minority said they would do so at weekends. They were apparently more likely to refer boys and younger children for renal tract imaging after a first urinary tract infection.

Conclusions-Urinary tract infection in children was underdiagnosed, and after a confirmed infection only a minority of patients received renal tract imaging or microbiological follow up. Greater awareness of the importance of investigation and management of urinary tract infection in children is needed, and the practical difficulties faced by general practitioners must be resolved.

\section{Introduction}

Optimal management of urinary tract infection in children is important because of the risk of renal scarring, especially in the presence of vesicoureteric reflux..$^{1-5}$ The risk of permanent damage is greatest in children aged under $2,{ }^{6-8}$ but diagnosis can be difficult in young children because symptoms such as fever, vomiting, screaming, anorexia, and irritability that may indicate urinary tract infection are common in other childhood illnesses such as gastroenteritis and viral infection. ${ }^{39}$ Diagnosis of urinary tract infection in children requires confirmation by finding a single organism at a concentration of at least $100 \times 10^{6} / 1$ in a fresh sample of urine. ${ }^{1011}$ It is, however, particularly difficult to obtain a sample of urine free of contamination from children who have not achieved bladder control.

Recently an expert multidisciplinary working group of the Royal College of Physicians proposed guidelines for the investigation and management of children with urinary tract infection. ${ }^{11}$ The group emphasised the importance of making a bacteriological diagnosis, of instituting treatment without delay after a urine sample is taken, and of checking for eradication of infection by means of a follow up urine specimen. The group also recommended that all children, regardless of gender, should have renal tract imaging after a first episode of confirmed urinary tract infection and gave recommendations on the type of imaging for 
each age group. For example, it recommended that children aged under 1 should be investigated with an ultrasound examination, a plain abdominal radiograph, micturating cystourethrogram, and a radionuclide renal scan. Less intensive investigation was suggested for older children.

The aims of this study were to determine the total number of childhood urinary tract infections confirmed by culture in the Gloucester health district over one year, to ascertain the proportion of children aged under 2 referred for renal tract imaging, and to assess the attitudes of general practitioners towards the investigation and management of urinary tract infection in childhood.

\section{Subjects and methods}

The number of children aged under 15 registered with each of the 53 general practices in the district (population 320000 ) served by the Gloucestershire Royal Hospital were obtained from the Family Health Services Authority's computer records. At the time of the study the 53 practices surveyed used Gloucester Public Health Laboratory and the departments of paediatrics and radiology at Gloucestershire Royal Hospital almost exclusively for their respective services. A transport service for the collection of urine specimens was provided to all practices each weekday. None of the practices was served by transport systems from other laboratories during the study.

\section{Microbiology}

Details of all the urine samples from children aged under 15 that were sent by general practitioners and hospital doctors to the public health laboratory for microbiological investigation were recorded prospectively for one year from 22 April 1991. All the samples were taken for clinical reasons and not as part of a screening programme. Bacteriological examination of urine was done by means of standard methods: inverted microscopy and quantitative culture on cystine-lactose electrolyte deficient medium. Urine samples more than 24 hours old on receipt in the laboratory were not examined.

Samples were recorded as positive if they yielded a single organism at a concentration of more than $100 \times 10^{6} / 1$ after overnight incubation. Pyuria was defined as the presence of 10 or more white blood cells in the field of view of a microscope under high power magnification. A follow up urine specimen was defined as one submitted for microbiological investigation one to four weeks after the submission of a previous positive specimen.

\section{RENAL TRACT IMAGING}

The radiological records of all children aged under 2 who had a positive urine culture were checked to see if they had been referred for imaging and, if so, what type of imaging had been undertaken.

\section{GENERAL PRACTITIONER QUESTIONNAIRE}

A two part questionnaire was sent to all general practitioners in the district at the end of the survey in order to measure their attitudes towards the investigation and management of urinary tract infections in children. The first part dealt with the practice of taking urine specimens for bacteriological examination, and the second part covered which children general practitioners would refer for radiological investigation. A second copy of the questionnaire was sent to nonresponders.

\section{STUDY CONSENT}

In order to avoid changes in patterns of laboratory usage general practitioners were not notified in advance of the start of the study. Permission to carry out the study was obtained from the medical director of Gloucestershire Family Health Services Authority.

\section{STATISTICAL METHODS}

Two by two $\chi^{2}$ tests and $\chi^{2}$ tests for linear trend were used where appropriate to estimate the significance of differences between proportions. Pearson's correlation coefficient was used to measure correlation between sets of variables.

\section{Results}

\section{URINE SAMPLES}

Table I shows the populations of children aged under 15 and under 2 who were registered with a general practice in the Gloucester district and the proportions of positive urine samples in each age group. The mean numbers of children aged under 15 and under 2 registered with each general practice were 1084 (range 354-2818) and 135 (45-395) respectively. The proportion of confirmed urinary tract infection in children aged under 15 was $1.0 \%(563 / 57432)$, with the proportions in boys and girls being $0.5 \%$ and $1.5 \%$ respectively. There was no apparent effect of season on the numbers of specimens submitted or on the numbers of positive cultures.

TABLE I-Urine samples taken from children aged under 15 and under 2 in Gloucester health district in one year for investigation of urinary tract infection

\begin{tabular}{lcccc}
\hline Age group & Population & $\begin{array}{c}\text { No of } \\
\text { samples } \\
\text { taken }\end{array}$ & $\begin{array}{c}\text { No (\%) of } \\
\text { infected } \\
\text { urine } \\
\text { samples }\end{array}$ & $\begin{array}{c}\text { No of } \\
\text { children with } \\
\text { infected urine } \\
\text { samples }\end{array}$ \\
\hline $\begin{array}{r}\text { <15 years } \\
<2 \text { years }\end{array}$ & 57432 & 4317 & $563(13 \cdot 0)$ & 442 \\
& 7143 & 821 & $103(12 \cdot 5)$ & 89 \\
\hline
\end{tabular}

A follow up urine sample was received in 125/563 cases. In a further 41 cases a second sample was received four to eight weeks after an initial positive sample.

The median rate of referral of urine samples to the laboratory by general practitioners was $5 \cdot 1$ (range $1 \cdot 0$ 11.4 ) specimens per year per 100 children registered with the practice. The figure shows the relation between the rate of referral of urine samples and the rate of finding positive samples for each practice. The correlation between the two rates was significant $(p<0.001)$. The median number of urine samples from children aged under 2 sent to the laboratory by general practitioners was $2 \cdot 3(0-13 \cdot 2)$ specimens per year per 100 children aged under 2 registered with the practice. Positive specimens without pyuria were found significantly more often in children aged under 2 than in older children $\left(80 / 103 v 162 / 460, \chi^{2}=61.9,1\right.$ degree of freedom, $\mathrm{p}<0.001)$.

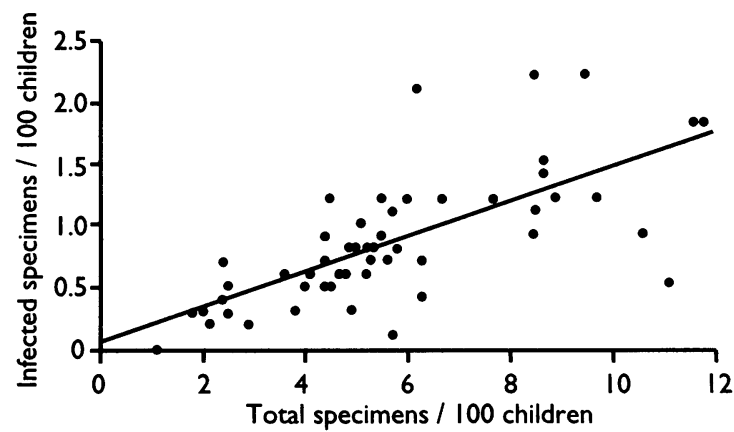

Relation between general practices' rate of referral of urine samples for investigation of urinary tract infection and rate of confirmation of infection. Each point represents a general practice (correlation coefficient $=0 \cdot 69, p<0 \cdot 001$, slope of line $=0 \cdot 15$ ) 


\section{RENAL TRACT IMAGING}

Of the 89 children aged under 2 with infected specimens, 28 underwent some form of imaging of the renal tract. All 28 had an ultrasound examination, while 10 had a micturating cystourethrogram, 13 had a technetium dimercaptosuccinic acid (DMSA) scan, and five had a plain abdominal radiograph taken as well. Table II shows the proportions of these children who were investigated subdivided according to the presence or absence of pyuria in their urine samples. Of the 19 children with a positive urine sample and pyuria, 13 had no renal tract imaging.

TABLE II-Referral by general practitioners and hospital doctors of children aged under 2 with infected urine samples (with or without pyuria) for imaging of the renal tract. Values are numbers of children

\begin{tabular}{|c|c|c|}
\hline & \multicolumn{2}{|c|}{ Pyuria } \\
\hline & Present & Absent \\
\hline Referred: & 6 & 22 \\
\hline By hospital doctor & 3 & 16 \\
\hline By general practitioner & 3 & 6 \\
\hline Not referred: & 13 & 48 \\
\hline By hospital doctor & 1 & 32 \\
\hline By general practioner & 12 & 16 \\
\hline
\end{tabular}

\section{GENERAL PRACTITIONER QUESTIONNAIRE}

Altogether $93 \%(182 / 195)$ of general practitioners replied to the questionnaire. Table III shows the responses to the first question, and table IV shows the responses to the second question. The general practitioners said that they were more likely to refer younger rather than older children for investigation after a first episode of urinary tract infection $\left(\chi^{2}=11.4\right.$, $\mathrm{df}=2, \mathrm{p}=0.00075)$ and boys rather than girls $\left(\chi^{2}=17 \cdot 6\right.$, $\mathrm{df}=2, \mathrm{p}=0.00003$ ). Most would refer boys and girls at all three ages for investigation after a second confirmed urinary tract infection.

\section{Discussion}

The principal finding of this study is that urinary tract infection in children is underdiagnosed and underinvestigated. There was a more than 10-fold difference between general practices in the rate of referral of children's urine samples to the laboratory and in the rate of culture confirmed urinary tract infection. Some children with urinary tract infections

TABLE III-Responses of 182 general practitioners to the cited quesion. Values are numbers of doctors who ticked each answer

\begin{tabular}{|c|c|c|}
\hline $\begin{array}{l}\text { Investigation of urinary tract infection may vary according to circumstances, } \\
\text { including the availability of laboratory facilities. Please tick the answer which best } \\
\text { fits your usual practice when a child aged under } 14 \text { presents with suspected urinary } \\
\text { tract infection at a weekday surgery or at a weekend or bank holiday }\end{array}$ & $\begin{array}{c}\text { At } \\
\text { weekday } \\
\text { surgery }\end{array}$ & $\begin{array}{l}\text { At } \\
\text { weekend } \\
\text { or bank } \\
\text { holiday }\end{array}$ \\
\hline Treat without taking urine sample & 0 & 14 \\
\hline Treat without taking urine sample; take sample after treatment for testing & 2 & 51 \\
\hline $\begin{array}{l}\text { Treat without taking urine sample; take follow up sample if symptoms not } \\
\text { improved }\end{array}$ & 4 & 29 \\
\hline Dipstick test urine sample and treat if result suggests infection & 4 & 35 \\
\hline $\begin{array}{l}\text { Take urine sample for culture, start antibiotic treatment and change if necessary } \\
\text { according to sensitivity }\end{array}$ & 135 & 25 \\
\hline Take urine sample, await results, then start antibiotic treatment & 12 & 1 \\
\hline \multicolumn{3}{|l|}{ Inadequate responses: } \\
\hline More than one option ticked & 24 & 26 \\
\hline No option ticked & 1 & 1 \\
\hline Total & 182 & 182 \\
\hline
\end{tabular}

TABLE IV-Responses of 182 general practitioners to the cited question. Values are numbers of doctors who ticked each answer

\begin{tabular}{|c|c|c|c|c|c|c|}
\hline \multirow{2}{*}{$\begin{array}{l}\text { Would you consider renal tract investigation } \\
\text { after one or two confirmed urinary tract } \\
\text { infections in children at various ages? }\end{array}$} & \multicolumn{2}{|c|}{ Age 11 months } & \multicolumn{2}{|c|}{ Age 3 years } & \multicolumn{2}{|c|}{ Age 8 years } \\
\hline & Boy & Girl & Boy & Girl & Boy & Girl \\
\hline \multicolumn{7}{|l|}{ Yes: } \\
\hline After first infection & 141 & 96 & 126 & 56 & 108 & 26 \\
\hline After second infection & 24 & 61 & 49 & 102 & 61 & 122 \\
\hline No & 17 & 25 & 7 & 24 & 13 & 34 \\
\hline
\end{tabular}

may not have been seen by a general practitioner at all while others may have been seen and treated without a urine specimen being taken for culture. Therefore, the incidence of confirmed urinary tract infections measured in this study should not be taken to reflect the true incidence of this condition in children in the community.

The number of specimens submitted by each practice correlated closely with the number of confirmed urinary tract infections. Practices which sent the fewest specimens to the laboratory diagnosed the fewest urinary tract infections. This probably reflected underdiagnosis rather than variation in incidence because there was no evidence of clustering of incidence in certain practices, and most specimens taken in general practice were from older children so that the proportion of positive results due to contamination was likely to be low.

There are several possible reasons why urine samples for confirmation of infection or clearance may be sent from only a small proportion of children. Urinary tract infection may have non-specific symptoms and may not be considered, the need for bacteriological examination before treatment may not be recognised, or there may be difficulty in obtaining a satisfactory specimen from a young child and transporting it promptly to the laboratory.

Bacteriuria may occur in the absence of pyuria, but the finding that positive specimens from children under 2 were significantly less likely to be accompanied by pyuria than positive specimens from older children may reflect a higher proportion of contaminated specimens in the younger age group. Even if attempts are made to collect a specimen it is difficult to obtain clean urine samples from children before they are toilet trained and have achieved bladder control. Suprapubic aspiration of urine is the most reliable way to avoid contamination, but general practitioners cannot be expected to undertake this procedure on all young children with the non-specific symptoms which may indicate a urinary tract infection. Immediate microscopy of a fresh urine sample by clinicians has been advocated ${ }^{12-15}$ and has been carried out by interested paediatricians for some time. It has, however, not yet found wide support in general practice.

The purpose of the questionnaire was to measure the intentions of general practitioners with regard to the investigation and management of urinary tract infection in children rather than to assess current practice. The replies showed that most general practitioners would aim to establish a bacteriological diagnosis for a child with suspected urinary tract infection, suggesting that once the diagnosis is considered failure to recognise the need for culture of a urine specimen is probably not an important cause of underdiagnosis. The general practitioners would usually aim to treat urinary tract infections in children promptly before confirmation of the diagnosis, as recommended by the Royal College of Physicians' working group. ${ }^{11}$ Practical difficulties are probably responsible for the different diagnostic standards at weekends, when only $14 \%$ of responders would aim to arrange a urine culture before starting treatment. Lack of ancillary staff in the surgery and lack of a transport service for specimens may both contribute to underinvestigation at weekends.

Only a minority of children aged under 2 were referred for imaging of the renal tract, even if they had pyuria. Most children with pyuria who were not referred for renal imaging had been diagnosed in general practice. Children whose infections were diagnosed in hospital were more likely to be investigated if they had pyuria, but even some of this group were not referred despite a paediatric departmental policy to initiate renal tract imaging in all children with a proved 


\section{Clinical implications}

- Good management of urinary tract infections in children is important because of the risk of renal scarring

- In this study a more than 10 -fold difference existed between general practices in the rate of referral of urine samples for testing and in the rate of confirmation of urinary tract infection

- Only a minority of children aged under 2 with a confirmed infection were referred for renal tract imaging

- General practitioners' answers to a questionnaire showed that their views on the need for renal tract imaging differed from recent recommendations

- Greater awareness is needed of the importance of the investigation and management of children's urinary tract infections

urinary tract infection. The general practitioners' views on the need for renal tract imaging differed from those of the royal college's working group but may reflect previous teaching. The replies to the questionnaire showed that general practitioners would be more likely to refer boys than girls. Over $75 \%$ of respondents would plan to refer boys aged under 1 after a first episode of urinary tract infection, but only just over half would refer girls of the same age. Most would plan to refer both boys and girls of all ages after a second urinary tract infection.

This study shows that urinary tract infections in children in Gloucester health district are underinvestigated and may be underdiagnosed, that only a small proportion of children have a follow up urine specimen taken, and that only a minority of young children with confirmed infection are referred for renal tract imaging. We believe that these findings do not apply to the Gloucester district alone, where family practitioner standards are high, but probably reflect practice throughout the country.

We thank the secretarial staff of Gloucester Public Health Laboratory; Gloucester district general practitioners; Carol Price, Department of Radiology, Gloucestershire Royal Hospital; Mark Dempster, Gloucestershire Family Health Services Authority; and André Charlett, PHLS Communicable Disease Surveillance Centre.

1 Hodson CJ, Edwards D. Chronic pyelonephritis and vesicoureteric reflux Clin Radiol 1960;11:219-31.

2 Smellie J, Edwards D, Hunter N, Normand ICS, Prescod N. Vesico-ureteric reflux and renal scarring. Kidney Int 1975;8(suppl 4): S65-72.

3 Smellie JM, Hodson CJ, Edwards D, Normand ICS. Clinical and radiologica features of urinary tract infections in childhood. BMF 1964;ii:1222-6.

4 Smellie JM, Ransley PG, Normand ICS, Prescod N, Edwards D. Development of new scars: a collaborative study. $B M F$ 1985;290:1957-60.

5 Filly RA, Friedland GW, Govan DE, Fair WR. Development and progression of clubbing and scarring in children with recurrent urinary tract infections. Radiology 1974;113:145-53.

6 Birmingham Reflux Study Group. Prospective trial of operative versus nonoperative treatment of severe vesicoureteric reflux in children: five years' observation. $B M \mathcal{F} 1987 ; 294: 237-41$

7 Berg UB, Johansson SB. Age as a main determinant of renal functional damage in urinary tract infection. Arch Dis Child 1983;58:963-9.

8 Winberg J, Bollgren I, Källenius G, Möllby R, Svensson SB. Clinical pyelonephritis and focal renal scarring. A selected review of pathogenesis, prevention and prognosis. Pediatr Clin North Am 1982;29:810-4.

9 Littlewood JM. 66 infants with urinary tract infection in first month of life. Arch Dis Child 1972;47:218-26.

10 Kass EH. Bacteriuria and the diagnosis of infections of the urinary tract with observations on the use of methionine as a urinary antiseptic. Arch Intern Med 1957;100:709-14.

11 Guidelines for the management of acute urinary tract infection in childhood. Report of a working group of the Research Unit, Royal College of Physicians. $7 R$ Coll Physicians Lond 1991;25:36-42.

12 Vickers D, Ahmad T, Coulthard MG. Diagnosis of urinary tract infection in children: fresh urine microscopy or culture? Lancet 1991;338:767-70.

13 Ditchburn RK, Ditchburn JS. A study of microscopical and chemical tests for the rapid diagnosis of urinary tract infections in general practice. $\mathrm{Br} \mathcal{F} \mathrm{Gen}$ Pract 1990;40:406-8.

14 White RHR. Management of urinary tract infection. Arch Dis Child 1987;62: 421-7.

15 Verrier Jones K. Antimicrobial treatment for urinary tract infections. Arch Dis Child 1990;65:327-30.

(Accepted 22 fuly 1993)

\title{
Prospective study of prenatal screening for Down's syndrome with free $\beta$ human chorionic gonadotrophin
}

\author{
Kevin Spencer, Paul Carpenter
}

\begin{abstract}
Objective-To assess the value and impact of a screening programme for Down's syndrome that uses the two maternal serum markers: $\alpha$ fetoprotein and free $\beta$ human chorionic gonadotrophin.

Design-All women booked into clinics were screened. Further tests were offered to women with a risk of one in $\mathbf{3 0 0}$ or greater of having an affected baby. Follow up of outcome of all pregnancies.

Setting-Biochemical screening laboratory serving two health districts.

Subjects -8179 women of all ages with singleton pregnancies screened between 15 and 22 weeks' gestation from 1 April 1991 to 31 March 1992.

Main outcome measures-Detection rate of Down's syndrome, false positive rate, uptake of screening, uptake of amniocentesis in women identified as at increased risk, prevalence of Down's syndrome at birth.

Results-Overall 89\% (8317/9345) of women underwent screening. The rate of detection of Down's syndrome was $69 \%(11 / 16 ; 95 \%$ confidence interval 41 to $89 \%$ ) with a $5 \cdot 2 \%$ false positive rate $(426 / 8179 ; 4.7$ to $5 \cdot 7 \%$ ). In women under 30 the detection rate was $50 \%$ (four out of eight; 32 to $86 \%$ )
\end{abstract}

Uptake of amniocentesis was 89\% (389/437), resulting in a reduction of prevalence of Down's syndrome at birth from 1.1 per 1000 in previous years $(66 / 59696)$ to 0.4 per 1000 during the screening year (4/9345). Additionally, several other abnormalities were identified.

Conclusion-The benefit of a high detection rate with this approach and the additional anomalies identified should encourage others to introduce screening programmes for Down's syndrome that use free $\beta$ human chorionic gonadotrophin and $\alpha$ fetoprotein.

\section{Introduction}

In 1984 Merkatz et al observed a link between low maternal serum concentration of $\alpha$ fetoprotein in the second trimester and babies affected by fetal trisomy. Cuckle et al subsequently confirmed this observation and proposed a screening programme for Down's syndrome (trisomy 21) based on the use of specified cut off values of $\alpha$ fetoprotein at various maternal ages. $^{2}$ Detection rates for Down's syndrome with this procedure at best would achieve a rate of detection of $30 \%$, with false positive rates often as high as $10 \%$. $^{3}$ 